\title{
PEMANFAATAN AMPAS TEBU UNTUK MENINGKATKAN KUALITAS (SIFAT ORGANOLEPTIK, PARAMETER OKSIDASI, DAN PROFIL ASAM LEMAK) PADA MINYAK JELANTAH
}

\author{
Winda Tri Wahyuni, Mia Srimiati \\ Sekolah Tinggi Ilmu Kesehatan Binawan \\ Email:windatriwabyuni53@gmail.com
}

\begin{abstract}
Used cooking oil is widely used by Indonesian people to fry many foods, which is the oil have been oxidized. On the other hand, Indonesia has a lot of unutilized waste products, such as bagasse. The design of the study was experimental, which added the bagasse to the used cooking oil to filtrate the physical and chemical impurities. There were 3 kinds of treatments, i.e. F1 (3\% of bagasse), F2 (5\% bagasse), F3 (7\% bagasse), and control (without bagasse). The characteristics of used cooking oil (control) were: dark brown, rancid odor, having $0,39 \%$ of free fatty acid, $12,39 \mathrm{meq} / \mathrm{Kg}$ of peroxide value, 35,52\% $\mathrm{w} / \mathrm{w}$ palmitic acid, 35,31 oleic acid, 9,35\% w/w linoleic acid, and $3,32 \% \mathrm{w} / \mathrm{w}$ stearic acid. The best treatment taken on the highest yield, organoleptic test, and peroxide number was F1 (3\% bagasse), it could reduced free fatty acid and peroxide value become $0,26 \%$ and $6,67 \mathrm{mEq} / \mathrm{kg}$. The number of fatty acids from the best treatment were dominated by palmitic acid $(33,94 \% \mathrm{w} / \mathrm{w})$, oleic acid (33,92\% w/w), linoleic acid (9,03\% w/w) and also had stearic acid $(3,21 \% \mathrm{w} / \mathrm{w})$. The bagasse can significantly reduce the organoleptic properties, the oxidation parameters, and other fatty acids of used oil $(\mathrm{P}<0,05)$. So, the bagasse could potentially decrease the oxidation parameters of used cooking oil.
\end{abstract}

Keywords: bagasse, cooking oil, oxidation parameters, fatty acid 


\section{PENDAHULUAN}

Minyak goreng adalah minyak nabati yang telah dimurnikan dan dapat digunakan sebagai bahan pangan, serta merupakan salah satu kebutuhan penting yang dibutuhkan oleh masyarakat Indonesia (Dewi et al. 2012). Konsumsi minyak goreng per kapita penduduk Indonesia tahun 2011 sebesar 8,24 liter/kapita/tahun (SUSENAS 2012). Di Indonesia, kebiasaan menggunakan minyak goreng berulang-ulang masih terbilang cukup tinggi, yaitu penggunaan minyak lebih dari dua kali mencapai 24\% (Ilmi et al. 2015). Hal ini menyebabkan minyak dapat mengalami kerusakan selain kontak dengan air, udara, dan logam (Prastagani 2016). Kerusakan minyak akibat pemanasan selama proses penggorengan akan mempengaruhi mutu dan nilai gizi dari bahan pangan yang digoreng (Noriko et al. 2012).

Kualitas minyak sangat dipengaruhi oleh angka asam yang menunjukkan kadar asam lemak bebas yang terkandung di dalam minyak (Noriko et al. 2012). Angka asam yang tinggi pada minyak jelantah diakibatkan oleh proses hidrolisis pada saat proses penggorengan. Angka asam dapat diturunkan dengan proses adsorpsi (Mardina et al. 2012).

Ampas tebu merupakan salah satu adsorben yang efektif untuk digunakan (Ramdja, Lisa, dan Daniel, 2010; Ratno, Mawarani, dan Zulkifli., 2013). Ampas tebu dapat digunakan sebagai bahan penyerap yang efektif untuk pemurnian minyak jelantah agar dapat dipakai kembali dalam keadaan bersih. Ampas tebu mengandung senyawa selulosa dan lignin sehingga dapat membantu proses penyerapan asam lemak bebas pada minyak jelantah (Ratno, Mawarani, dan Zulkifli, 2013).

Oleh karena itu, penelitian tertarik untuk menjernihkan minyak jelantah dengan menggunakan adsorben ampas tebu dengan waktu 7 jam perendaman sehingga diharapkan dengan waktu yang singkat tetap dapat meningkatkan kualitas minyak jelantah untuk menambah masa pakai dan mengurangi efek negatif yang ditimbulkan akibat pemakaian yang berulang.

\section{BAHAN DAN METODE}

Penelitian ini bersifat eksperimental. Selanjutnya dilakukan uji hedonik dan mutu hedonik terkait warna, aroma, dan keseluruhan produk serta dilakukan analisis parameter oksidasi, lalu produk terbaik di uji profil asam lemaknya. Ampas tebu diperoleh dari pedagang penjual es tebu. Sisa-sisa penggilingan sari tebu dicuci hingga bersih lalu dikeringkan di bawah terik matahari. Selanjutnya ampas tebu yang telah dikeringkan dihaluskan dan diayak hingga didapatkan bubuk ampas tebu. Sedangkan minyak goreng bekas 
didapat dari pedagang gorengan yang telah digunakan lebih dari 10x penggorengan untuk digunakan sebagai bahan baku proses analisis.

Alat untuk produk atau sampel penelitian yaitu blender, ayakan 110 mesh, sendok, kertas saring, dan baskom, serta alat untuk analisis yaitu timbangan bahan makanan, labu erlenmeyer, alat titrasi, beaker gelas, hot plate, stirrer, pipet tetes, pipet mikro, pipet volumetrik, termometer, penegas air, kertas saring, corong, neraca analitit, botol VCO, tabung tertutup teflon, gelas ukur, pH meter, cawan petri, spatula, perangkat Kromatografi gas, dan kamera untuk dokumentasi. Adapun bahan untuk produk atau sampel penelitian yaitu minyak goreng bekas pakai yang berasal dari minyak sawit dan ampas tebu, serta bahan untuk analisis yaitu larutan $\mathrm{NaOH} 0,5 \mathrm{~N}, \mathrm{BF}_{3} 20 \%, \mathrm{NaCl}$ jenuh, Heksan, $\mathrm{Na}_{2} \mathrm{SO}_{4}$ anhidrat, syringe $10 \mu \mathrm{L}$, asam sitrat, asam stearat, indikator PP, gliserin, etanol, dan aquadest.

\section{HASIL DAN PEMBAHASAN}

Proses penjernihan minyak jelantah dilakukan melalui beberapa tahap, yaitu penimbangan, perendaman, dan penyaringan (Ratno et al. 2013). Minyak jelantah pada setiap perlakuan diberikan persentase penambahan ampas tebu yang berbeda-beda, yaitu 3\%, 5\%, dan 7\%. Persentase penambahan ampas tebu pada setiap perlakuan mempengaruhi persentase rendemen minyak yang didapat.

\section{Penentuan rendemen}

Rendemen adalah perbandingan jumlah (kuantitas) minyak yang dihasilkan dari proses penyaringan. Rendemen menggunakan satuan persen (\%) (Armando 2009). Hasil rendemen minyak jelantah pada setiap perlakuan berbeda-beda, yaitu perlakuan 1 (penambahan ampas tebu 3\%) sebesar 72\%, perlakuan 2 (penambahan ampas tebu 5\%) sebesar 55\%, dan perlakuan 3 (penambahan ampas tebu 7\%) sebesar 39\%. Berdasarkan hasil sidik ragam menunjukkan bahwa perlakuan penambahan ampas tebu berpengaruh nyata $(p<0,05)$ terhadap persentase rendemen minyak jelantah yaitu semakin tinggi nilai rendemen yang dihasilkan menandakan nilai minyak jelantah yang dihasilkan semakin banyak. Hal ini dapat terjadi dikarenakan sifat ampas tebu yang dapat menyerap minyak, sehingga semakin banyak ampas tebu yang digunakan maka minyak yang diserap pun semakin banyak.

\section{Sifat organoleptik}

Uji organoleptik dilakukan pada panelis semi terlatih sebanyak 30 orang. Panelis merupakan mahasiswi Ilmu Gizi STIKes Binawan. Metode yang 
digunakan dalam pengukuran uji hedonik adalah menggunakan skala garis, dengan nilai yang berkisar antara 1 (sangat tidak suka) sampai dengan 7 (sangat suka). Hasil dari masing-masing penilaian dianalisis secara deskriptif dan statistik dengan uji beda lebih dari dua kelompok menggunakan analisis sidik ragam (ANOVA) kemudian dilanjutkan dengan uji lanjut Duncan. Hasil uji hedonik dan mutu minyak jelantah kontrol dan diberi perlakuan menggunakan ampas tebu dapat dilihat pada Tabel 1.

\section{Tabel 1 Uji Hedonik dan Mutu Hedonik}

\begin{tabular}{llllll}
\hline \multirow{2}{*}{ Formula } & \multicolumn{2}{l}{ Hedonik } & & \multicolumn{2}{l}{ Mutu Hedonik } \\
\cline { 2 - 6 } & Warna & Aroma & Keseluruhan & Warna & Aroma \\
\hline F0 $(0 \%)$ & $1,78^{\mathrm{a}}$ & $2,30^{\mathrm{a}}$ & $2,53^{\mathrm{a}}$ & $1,50^{\mathrm{a}}$ & $2,38^{\mathrm{a}}$ \\
F1 $(3 \%)$ & $4,31^{\mathrm{b}}$ & $3,93^{\mathrm{b}}$ & $4,31^{\mathrm{b}}$ & $3,55^{\mathrm{b}}$ & $3,66^{\mathrm{b}}$ \\
F2 $(5 \%)$ & $4,40^{\mathrm{b}}$ & $3,98^{\mathrm{b}}$ & $4,43^{\mathrm{b}}$ & $3,61^{\mathrm{b}}$ & $3,78^{\mathrm{b}}$ \\
F3 $(7 \%)$ & $4,63^{\mathrm{b}}$ & $4,10^{\mathrm{b}}$ & $4,45^{\mathrm{b}}$ & $3,80^{\mathrm{b}}$ & $3,83^{\mathrm{b}}$ \\
\hline
\end{tabular}

Keterangan:

- Hedonik : Skala 1 = sangat tidak suka hingga 7 = sangat suka

- Mutu hedonik:

a. warna skala $1=$ kuning kehitaman hingga $7=$ kuning pucat

b. aroma skala $1=$ sangat tengik, hingga $7=$ sangat harum

- Huruf yang beda pada baris yang sama menunjukkan perbedaan yang nyata $(p<0,05)$

\section{Warna}

Berdasarkan hasil sidik ragam, menunjukkan perlakuan penambahan ampas tebu berpengaruh nyata $(p<0,05)$ terhadap warna minyak jelantah maupun tingkat kesukaan panelis terhadap minyak jelantah hasil pemurnian. Hasil uji lanjut Duncan menunjukkan bahwa perbedaan konsentrasi penambahan ampas tebu pada minyak jelantah F1 (penambahan 3\% ampas tebu), F2 (penambahan 5\% ampas tebu), dan F3 (penambahan 7\% ampas tebu) tidak berbeda nyata, sedangkan konsentrasi penambahan ampas tebu pada minyak jelantah F0 (tanpa penambahan ampas tebu) berbeda nyata dengan F1 (penambahan 3\% ampas tebu), F2 (penambahan 5\% ampas tebu), dan F3 (penambahan 7\% ampas tebu) terhadap penilaian warna. Hal ini karena partikel ampas tebu dapat menyerap kotoran yang terdapat pada minyak jelantah sehingga minyak jelantah menjadi lebih jernih setelah diberi perlakuan (Hajar et al. 2016). 


\section{Aroma}

Berdasarkan sidik ragam, perlakuan penambahan ampas tebu berpengaruh nyata $(\mathrm{p}<0,05)$ terhadap aroma minyak jelantah maupun tingkat kesukaan panelis. Hasil uji lanjut Duncan menunjukkan bahwa perbedaan konsentrasi penambahan ampas tebu pada minyak jelantah F1 (penambahan 3\% ampas tebu), F2 (penambahan 5\% ampas tebu), dan F3 (penambahan 7\% ampas tebu) tidak berbeda nyata, sedangkan konsentrasi penambahan ampas tebu pada minyak jelantah F0 (tanpa penambahan ampas tebu) berbeda nyata dengan F1 (penambahan 3\% ampas tebu), F2 (penambahan 5\% ampas tebu), dan F3 (penambahan 7\% ampas tebu) terhadap penilaian aroma. Hal ini karena ampas tebu dapat mengurangi oksidasi pada minyak jelantah, yang mana oksidasi dapat menyebabkan ketengikan pada minyak (Prastagani 2016).

\section{Keseluruhan}

Berdasarkan sidik ragam, perlakuan penambahan ampas tebu berpengaruh nyata $(\mathrm{p}<0,05)$ terhadap tingkat kesukaan panelis pada keseluruhan minyak jelantah. Hasil uji lanjut Duncan menunjukkan bahwa perbedaan konsentrasi penambahan ampas tebu pada minyak jelantah F1 (penambahan 3\% ampas tebu), F2 (penambahan 5\% ampas tebu), dan F3 (penambahan 7\% ampas tebu) tidak berbeda nyata, sedangkan konsentrasi penambahan ampas tebu pada minyak jelantah F0 (tanpa penambahan ampas tebu) berbeda nyata dengan F1 (penambahan 3\% ampas tebu), F2 (penambahan 5\% ampas tebu), dan F3 (penambahan 7\% ampas tebu) terhadap penilaian keseluruhan produk. Hal ini diduga karena adanya perbedaan antara minyak jelantah sebelum dan sesudah ditambahkan ampas tebu sehingga penambahan ampas tebu berpengaruh secara signifikan terhadap tingkat kesukaan panelis pada keseluruhan minyak jelantah hasil pemurnian.

\section{Parameter oksidasi}

Hasil uji parameter oksidasi minyak jelantah sebelum dan sesudah diberi perlakuan dengan menggunakan ampas tebu disajikan pada tabel 2.

\section{Tabel 2 Parameter Oksidasi}

\begin{tabular}{ccc}
\hline Perlakuan & $\begin{array}{c}\text { Asam Lemak Bebas } \\
(\mathbf{\%} \mathbf{w} / \mathbf{w})\end{array}$ & $\begin{array}{c}\text { Bilangan Peroksida } \\
(\mathbf{m e q} / \mathbf{K g})\end{array}$ \\
\hline F0 & $0,39^{\mathrm{c}}$ & $12,39^{\mathrm{b}}$ \\
F1 & $0,26^{\mathrm{b}}$ & $6,67^{\mathrm{a}}$ \\
F2 & $0,22^{\mathrm{a}}$ & $11,38^{\mathrm{b}}$ \\
F3 & $0,20^{\mathrm{a}}$ & $10,46^{\mathrm{b}}$ \\
\hline
\end{tabular}




\section{Bilangan asam lemak bebas}

Hasil sidik ragam menunjukkan bahwa perlakuan penambahan ampas tebu berpengaruh nyata $(\mathrm{p}<0,05)$ terhadap penurunan bilangan asam lemak bebas pada minyak jelantah. Hasil uji lanjut Duncan menunjukkan bahwa perbedaan nilai asam lemak bebas pada minyak jelantah F2 (penambahan 5\% ampas tebu) dan F3 (penambahan 7\% ampas tebu) tidak berbeda nyata, sedangkan pada minyak jelantah F0 (tanpa penambahan ampas tebu) dan F1 (penambahan 3\% ampas tebu) berbeda nyata terhadap F2 (penambahan 5\% ampas tebu) dan F3 (penambahan 7\% ampas tebu). Hal ini dikarenakan ampas tebu mengandung senyawa selulosa dan lignin, dimana yang berperan adalah gugus $\mathrm{OH}$ yang terikat pada senyawa tersebut, sehingga dapat membantu proses penyerapan asam lemak bebas pada minyak jelantah.

\section{Bilangan peroksida}

Hasil sidik ragam menunjukkan bahwa perlakuan penambahan ampas tebu berpengaruh nyata $(\mathrm{p}<0,05)$ terhadap bilangan peroksida pada minyak jelantah. Hasil uji lanjut Duncan menunjukkan bahwa nilai analisis bilangan peroksida pada minyak jelantah F0 (tanpa penambahan ampas tebu), F2 (penambahan 5\% ampas tebu), dan F3 (penambahan 7\% ampas tebu) tidak berbeda nyata, sedangkan nilai analisis bilangan peroksida pada minyak jelantah F1 (penambahan ampas 3\% ampas tebu) berbeda nyata terhadap minyak jelantah F0 (tanpa penambahan ampas tebu), F2 (penambahan 5\% ampas tebu), dan F3 (penambahan 7\% ampas tebu).

\section{Profil asam lemak Analisis profil asam lemak pada formula terpilih}

Asam lemak yang terkandung di dalam minyak sangat menentukan mutu dari minyak, karena asam lemak tersebut menentukan sifat kimia dan stabilitas minyak (Noriko et al. 2012). Pada penelitian ini minyak jelantah yang terpilih yaitu F1 (minyak dengan penambahan 3\% ampas tebu) diuji profil asam lemaknya. Hasil analisis profil asam lemak pada minyak jelantah sebelum dan sesudah diberi perlakuan dengan menggunakan ampas tebu disajikan pada Tabel 3.

Data pada Tabel 3 menunjukkan bahwa proses pemurnian juga dapat menurunkan nilai asam lemak. Asam lemak palmitat (C16:0) sebelum pemurnian sebesar 35,52\%, turun menjadi 33,94\%; Asam stearat (C18:0) sebelum pemurnian 3,32\%, turun menjadi 3,21\%; Asam lemak oleat (C18:1) sebelum pemurnian sebesar 35,31\%, turun menjadi 33,92\%; asam lemak linoleat (C18:2) sebelum pemurnian sebesar 9,35\%, turun menjadi 9,03\%; asam lemak linolenat (C18:3) sebelum pemurnian 0,24\%, turun menjadi $0,23 \%$. 
Tabel 3 Hasil Pengujian Asam Lemak

\begin{tabular}{lccc}
\hline \multicolumn{1}{c}{ Asam Lemak $(\% \mathrm{w} / \mathrm{w})$} & Sebelum & Terpilih (F1) & P-value \\
\hline Asam Kaprilat & 0,05 & 0,04 & 0,553 \\
Asam Laurat (C12:0) & 0,13 & 0,13 & 1,000 \\
Asam Miristat (C14:0) & 0,68 & 0,66 & 0,553 \\
Asam Pentadekanoat (C15:0) & 0,03 & 0,03 & 1,000 \\
Asam Palmitat (C16:0) & 35,52 & 33,94 & $0,000^{*}$ \\
Asam Heptadekanoat (C17:0) & 0,07 & 0,07 & 1,000 \\
Asam Stearat (C18:0) & 3,32 & 3,21 & $0,532^{*}$ \\
Asam Arakidonat (C20:0) & 0,24 & 0,24 & 1,000 \\
Asam Behenat (C22:0) & 0,05 & 0,05 & 1,000 \\
Asam Lignoceric (C24:0) & 0,05 & 0,05 & 1,000 \\
\hline \multicolumn{1}{c}{ Total Asam Lemak Jenuh } & 40,14 & 38,42 & \\
\hline Asam Palmitoleat & 0,10 & 0,10 & 1,000 \\
Asam Oleat (C18:1) & 35,31 & 33,92 & $0,000^{*}$ \\
Asam Elaidat (C18:1) & 0,16 & 0,15 & 0,698 \\
Asam Linoleat (C18:2) & 9,35 & 9,03 & $0,008 *$ \\
Asam Linolenat (C18:3) & 0,23 & 0,24 & 0,757 \\
Asam Cis-11-Eikosanoat (C20:1) & 0,08 & 0,06 & 0,553 \\
\hline Total Asam Lemak Tak Jenuh & 45,23 & 43,5 & \\
\hline \multicolumn{1}{c}{ Total Asam Lemak } & 85,37 & 81,92 & \\
\hline
\end{tabular}

\section{Asam lemak palmitat (C16:0)}

Persentase asam palmitat (C16:0) pada minyak jelantah setelah proses pemurnian tanpa penambahan ampas tebu (kontrol) adalah 35,52\% sedangkan pada produk minyak jelantah terpilih (penambahan ampas tebu 3\%) sebesar $33,94 \%$. Hasil sidik ragam menunjukkan bahwa perlakuan penambahan ampas tebu berpengaruh nyata $(\mathrm{p}<0,05)$ terhadap asam palmitat $(\mathrm{C} 16: 0)$ pada minyak jelantah.

\section{Asam lemak stearat (C18:0)}

Minyak jelantah hasil pemurnian tanpa penambahan ampas tebu (kontrol) mengandung asam stearat sebesar 3,32\% sedangkan kandungan asam lemak stearat (C18:0) pada minyak jelantah terpilih (penambahan ampas tebu $3 \%$ ) sebesar 3,21\%. Berdasarkan hasil sidik ragam, perlakuan penambahan ampas tebu tidak berpengaruh nyata terhadap kandungan asam lemak stereat (C18:0) pada minyak jelantah.

Penurunan asam lemak jenuh (palmitat) menunjukkan hasil yang signifikan namun tidak pada asam lemak jenuh (stereat) hal ini disebabkan karena asam lemak palmitat yang cukup jenuh sehingga ketika disaring asam lemak sedikit yang lolos pada proses penyaringan. 


\section{Asam lemak oleat (C18:1)}

Kandungan asam lemak oleat (C18:1) pada minyak jelantah hasil pemurnian tanpa penambahan ampas tebu (kontrol) adalah sebesar 35,31\% sedangkan kandungan asam lemak oleat (C18:1) pada minyak jelantah perlakuan yang merupakan produk terpilih (penambahan ampas tebu 3\%) sebesar 33,92\%. Terjadi penurunan asam lemak oleat, itu berarti ketengikan dan asam lemak trans pada minyak pun berkurang. Karena asam lemak tak jenuh dari minyak goreng yang telah dipakai berulang akan menjadi asam lemak trans yang tidak baik untuk kesehatan (Tuminah 2009). Berdasarkan hasil sidik ragam, perlakuan penambahan ampas tebu berpengaruh nyata $(\mathrm{p}<0,05)$ terhadap kandungan asam lemak oleat $(\mathrm{C} 18: 1)$ pada minyak jelantah.

\section{Asam lemak linoleat (C18:2)}

Kandungan asam lemak linoleat (C18:2) pada minyak jelantah kontrol (pemurnian tanpa penambahan ampas tebu) adalah sebesar 9,35\% sedangkan kandungan asam linoleat (C18:2) pada minyak jelantah perlakuan yang merupakan produk terpilih (penambahan ampas tebu 3\%) yaitu sebesar 9,03\%. Berdasarkan hasil sidik ragam, perlakuan penambahan ampas tebu berpengaruh nyata $(\mathrm{p}<0,05)$ terhadap kandungan asam lemak linoleat $(\mathrm{C} 18: 2)$ pada minyak jelantah.

Penurunan asam lemak tak jenuh (oleat dan linoleat) menunjukkan hasil yang signifikan hal ini disebabkan oleh berat molekul pada asam lemak oleat dan linoleat yang cukup tinggi sehingga tidak lolos pada proses penyaringan. Asam lemak tak jenuh memiliki sifat yang mudah teroksidasi sehingga semakin banyak jumlah asam lemak tak jenuh maka semakin cepat pula lemak/minyak akan teroksidasi. Lemak/minyak yang teroksidasi dapat menyebabkan kanker (Simanjuntak 2015).

\section{KESIMPULAN}

Berdasarkan hasil penelitian yang telah dilakukan, dapat disimpulkan bahwa ampas tebu cukup efektif digunakan untuk pemurniann minyak jelantah sehingga dapat mengurangi efek negatif dari minyak jelantah yang sudah teroksidasi. Penelitian lebih lanjut tentang pemurnian minyak jelantah dengan adsorben berupa ampas tebu, diantaranya dengan variasi waktu pada setiap perlakuan untuk melihat pengaruh lama perendaman terhadap karakteristik minyak. 


\section{DAFTAR PUSTAKA}

Armando R. 2009. Memproduksi 15 Minyak Asiri Berkualitas. Bogor: Penebar Swadaya.

Badan Pusat Statistik. 2012. Survey Sosial Ekonomi Nasional

Dewi MTI. \& Hidajati N. 2012. Peningkatan mutu minyak goreng curah menggunakan adsorben bentonit teraktivasi. UNES A Journal of Chemistry, 1(2):47-53

Hajar EW, Purba1 AF, Handayani1 P, dan Mardiah. 2016. Proses Pemurnian Minyak Jelantah Menggunakan Ampas Tebu Untuk Pembuatan Sabun Padat. Jurnal Integrasi Proses 6(2): 57-63.

Ilmi I, Khomsan. A, Marliyati. S, 2015. Kualitas minyak goreng dan produk gorengan selama penggorengan di rumah tangga indonesia. Jurnal Aplikasi Teknologi Pangan. 4(2):61-65

Mardina P, Faradina E, dan Setiawati, N. 2012. Penurunan angka asam pada minyak jelantah. Jurnal kimia 6 (2):196-200.

Noriko N, Elfidasari D, Perdana AT, Wulandari N, Wijayanti W. 2012. Analisis penggunaan dan syarat mutu minyak goreng pada penjaja makanan di food court UAI. Jurnal Al-ąhar Indonesia seri sains dan teknologi, 1(3):147-154

Prastagani W. 2016. Pengaruh frekuensi penggorengan terhadap angka asam dan peroksida minyak jelantah dari kremes yang ditambahkan tepung kunyit. (Disertasi) Universitas Muhamadiyah Surakarta Fakultas Ilmu Kesehatan: Surakarta

Ramdja A, Lisa F, dan Daniel K. 2010. Pemurnian minyak jelantah menggunakan ampas tebu sebagai adsorben. Jurnal Teknik Kimia, 1(17):714.

Ratno, Mawarani LJ, dan Zulkifli. 2013. Pengaruh ampas tebu sebagai adsorbent pada proses pretreatment minyak jelantah terhadap karakteristik biodiesel. Jurnal Teknik Pomits, 2(2):257-251

Simanjuntak TP. 2014. Komponen Giz̨i Dan Terapi Pangan Ala Papua. Yogyakarta: Deepublish. 